https://doi.org/10.19195/2084-2546.28.9

\author{
KATARZYNA SETKOWICZ \\ ORCID: 0000-0001-5972-7341 \\ Uniwersytet Wrockawski \\ Correo: katarzyna.setkowicz@uwr.edu.pl
}

\title{
El abrazo de Almanzor: Nota sobre una huella de Adam Mickiewicz en la obra de Manuel González Prada
}

\author{
Palabras clave: Manuel González Prada — Adam Mickiewicz — baladas — \\ Polonia.
}

\section{Resumen}

Este trabajo tiene como objetivo señalar un tema que debe ser analizado en el contexto de la obra de Manuel González Prada, es decir, la influencia de las composiciones de un romántico polaco, Adam Mickiewicz. La autora señala los pasajes tomados por González Prada directamente de la obra de Mickiewicz. Entre ellos aparecen no solo las traducciones oficiales, sino también fragmentos que no quedan claros para quienes no conocen la obra del poeta polaco. Un ejemplo evidente es el motivo del "abrazo de Almanzor", metáfora ideada por Mickiewicz, que González Prada utiliza al menos en dos ocasiones: como título de una balada inconclusa que pretendía ser una traducción libre de la balada de Mickiewicz, así como en sentido fraseológico, en uno de sus escritos políticos.

Hoy en día, Manuel González Prada (1844-1918) es conocido como uno de los autores más importantes de la cultura peruana, si no latinoamericana. Precursor del modernismo e indigenismo, en su obra presenta una doble faceta de político-ensayista y poeta, aunque las composiciones poéticas le sirvan también de vehículo para sus ideas políticas y sociales. Durante su vida llega a lanzar al mercado solo tres libros de poesías ${ }^{1}$, con las que no obstante logra ser un poeta reconocido. Sus Baladas, publicadas póstumamente por iniciativa ajena en 1935, son consideradas el poemario más importante de la literatura peruana decimonónica. Resulta curioso que el poeta, al dedicarse a crear la

\footnotetext{
1 Dos, si descontamos la edición privada de Minúsculas (1901) de tan solo 100 ejemplares.
} 
balada peruana y querer "encontrar la más viva entraña de la peruanidad" 2 , se deje estimular sobre todo por la poesía alemana y francesa. La obra de González Prada bebe tanto de la cultura literaria como de la realidad europeas. Él mismo afirma en uno de sus escritos: "Las ideas que más propias se nos figuran, nos vienen del medio intelectual en que respiramos o de la atmósfera artificial que nos formamos con la lectura. Lo que damos a unos, lo hemos tomado de otros"3.

Por consiguiente, para el autor peruano tanto la literatura como las circunstancias históricas constituyen una materia prima, un punto de partida desde el que se realiza el proceso de transformación dentro del marco de una intertextualidad que se ve reflejada tanto en su obra ensayística, como poética. De hecho, según sostiene Joël Delhom, "más de un millar de referencias salpican la obra completa de González Prada", donde por referencia se entiende "la mención de un autor, de un personaje histórico o de un personaje de ficción, de una obra lato sensu [...], una cita explícita o incluso una alusión"4. Entre las fuentes señaladas por Delhom no encontramos, sin embargo, ni una sola mención de autores polacos 5 .

Viajemos ahora unos doce mil kilómetros al noreste de Lima. En 1828 sale de las prensas de Karol Kray en San Petersburgo uno de los más famosos poemas narrativos de la literatura polaca, Konrad Wallenrod de Adam Mickiewicz (1798-1855). El gran romántico compone la obra durante su exilio en Rusia, entre el año 1825 y 1828 . El argumento del poema se remonta a la Edad Media y cuenta la historia de Konrad Wallenrod, un pagano de Lituania que es capturado por la Orden Teutónica, se convierte al cristianismo y con el tiempo, gracias a su astucia, llega a ocupar el puesto de Gran Maestro de la Orden. Sin embargo, el protagonista de la obra no se vuelve contra sus compatriotas. En realidad, ha dejado a su amada y a todo lo que quería para vengarse, a fin de llevar a cabo un plan traidor y fraudulento, excusado, no obstante, por la situación en la que se encuentra su patria, oprimida por los teutones.

Durante un gran banquete en honor a San Jorge, un bardo canta la historia de Walter Alf(el nombre verdadero de Konrad Wallenrod), dejándola inconclusa, ya que todavía no se ha realizado la venganza del pueblo lituano. Es entonces cuando el mismo Konrad coge el laúd y se pone a cantar una balada. Ésta, titulada La Alpujarra, se convertirá en uno de los pasajes más famosos de la obra y llegará a servir de inspiración a varios poetas y dramaturgos polacos. Dentro de la obra, la balada anticipa los planes de Konrad y el final de todo p. 753.

2 E. Núñez, "Manuel González Prada y la poesía”, Revista Hispánica Moderna, 34, 1968,

3 M. González Prada, Horas de lucha, Lima, Ediciones Futuro, 1964, p. 38.

4 J. Delhom, "Aproximación a las fuentes del pensamiento filosófico y político de Manuel González Prada: un bosquejo de biografía intelectual", Iberoamericana, 42, 2011, p. 22.

5 Aquí son necesarias dos matizaciones. Según afirma el autor, "No aparecen las citas cuya frecuencia es inferior a cinco", ibidem, p. 24. Por otro lado, Joël Delhom incluye al sociólogo polaco, Ludwik Gumplowicz, entre los autores alemanes, con una frecuencia de cita entre 5 y 9 , ibidem, p. 26. 
el poema. Mickiewicz sitúa la trama del canto durante la conquista de Granada, cometiendo al mismo tiempo un doble anacronismo. Primero, al emplazar la historia a tiempos posteriores a la posible guerra con la Orden Teutónica y la vida del personaje histórico de Konrad von Wallenrode (que efectivamente fue gran maestre a finales del siglo XIV). Segundo, al nombrar al personaje principal Almanzor, uno de los protagonistas más emblemáticos de las luchas entre los bandos cristianos y el Califato de Córdoba en la Península Ibérica. El Almanzor histórico llegó al poder en un al-Andalus todavía esplendoroso y fuerte. De hecho, realizó numerosas campañas militares, deteniendo incluso de manera temporal el avance de los cristianos hacia el sur de la Península, siendo hoy en día muy famosas "dos de sus aparatosas proyecciones, contra los cristianos del Norte peninsular, con algaras sonadísimas, pues llegó a atacar, entre otras, Barcelona (en 985) y Santiago de Compostela (en 997)"6. Almanzor murió a principios del siglo XI en una época en la que la ciudad de Granada ni siquiera existía, sin hablar ya de la supuesta necesidad de su defensa.

La balada que nos llega a través de la obra de Mickiewicz es, por lo tanto, una pura invención del autor polaco que hace uso de varios motivos de la historia de la Reconquista, con un toque orientalizante, muy del gusto de los románticos, junto al motivo de la peste negra del siglo XIV. Almanzor sale de la ciudad cercada por los cristianos contagiado de peste y se entrega a los vencedores fingiendo querer avasallarse, mientras que está llevando a cabo su venganza. En un gesto de aparente amistad y sumisión, abraza al rey cristiano y, uno por uno, a sus generales, contagiándolos a todos. La actuación de Almanzor resulta contraria a los códigos caballerescos, pero al mismo tiempo se santifica por el coraje y la intención del que busca la venganza. De la misma manera se planifica la venganza de Walter Alf, que bajo su mando llevará a la Orden Teutónica a la perdición.

Ahora bien, el acontecimiento pseudohistórico imaginado por Adam Mickiewicz reaparece hasta dos veces entre los escritos de un autor tan lejano como el peruano Manuel González Prada. La inspiración no se nos muestra casual, dado que el poeta de Lima parece conocer la obra de Mickiewicz, aunque sea sólo a través de las traducciones francesas. Para empezar, encontramos una mención a la obra del polaco en su tratado Ortometría: apuntes para una ritmica $^{7}$, publicado en 1977. Pero sobre todo atrae nuestra atención una traducción libre de uno de los poemas de Mickiewicz titulado Panicz i dziewczyna, incluida en el Libro III de las baladas del peruano. Es una traducción de la versión francesa en prosa de Seigneur et jeune fille, cuya sentencia final aparece al principio del poema de González Prada a manera de un epígrafe:

${ }^{6}$ M.J. Viguera Molins, "Imágenes de Almanzor”, en: F. Valdés Fernández (ed.), Almanzor y los terrores del milenio, Aguilar de Campoo, Fundación Santa María la Real, 1999, p. 15.

7 M. González Prada, Ortometría: apuntes para una rítmica, Lima, Universidad Nacional Mayor de San Marcos, 1977, p. 64. 


\section{EL ENCUENTRO}

Pourtant, si j'ai bien lu dans ses yeux, dans son maintien, il ne demandait plus son chemin à la jeune fille.

MICKIEWICZ ${ }^{8}$

El epígrafe procede de la traducción realizada por otro poeta y escritor, Christien Ostrowski (pol. Krystyn Ostrowski), que emigra a Francia en 1831 y allí publica, entre otras, la traducción de obras completas de Adam Mickiewicz. Observamos que Manuel González Prada se inspira más bien en el poema de Mickiewicz, y no lo traduce literalmente, omitiendo y cambiando ciertos pasajes, de los que solo queda la idea principal de la composición. De este procedimiento trata Américo Ferrari hablando de las traducciones del alemán, pues en aquel caso, como en este, el logro de González Prada consiste en "el traslado a ritmos y metros tradicionales de la poesía hispánica de una atmósfera y de un espíritu"9. Ferrari llega a sostener incluso que "todas las composiciones incluidas en el volumen de Baladas son creaciones originales del poeta, incluso las traducciones"10.

Tal vez la misma intención guía al poeta peruano cuando ambiciona componer la balada titulada Almanzor, inspirado claramente en Mickiewicz. La balada, inconclusa (solo nos llega la primera estrofa), se encuentra en el así llamado "Cuaderno II" de los manuscritos. Según advierte el primer editor del conjunto de las Baladas y a la vez hijo del autor, Alfredo González Prada: "Una lista en la página final del mencionado Cuaderno II indica los títulos de diez baladas que el autor proyectó, pero no escribió. En ella, este poema lleva el nombre de El Abrazo de Almanzor"11. Dicha lista incluye títulos de varios poemas, de los que el poeta llega a trazar dos (dejándolos inconclusos): Los Mitimaes y El Sol de los Gentiles, y otros tres romances peruanos: Hernando Pizarro en Pachacamac, Los Tres Malditos y El Tesoro de Atahualpa ${ }^{12}$. Por su parte, Almanzor o El abrazo de Almanzor podría pertenecer al miniciclo de baladas inspiradas por el romancero español, sobre todo las dedicadas a la conquista musulmana, donde el poeta se sitúa claramente al lado de los invasores moros (El islamismo, El palacio de Toledo, Alfonso X).

La única estrofa de [El Abrazo de] Almanzor reza de tal manera:

Al empuje de Castilla

La altivez del moro cede:

8 M. González Prada, Baladas, Lima, Pontificia Universidad Católica de Perú, 2004, p. 225.

9 A. Ferrari, La soledad sonora: voces poéticas del Perú e Hispanoamérica, Lima, Pontificia Universidad Católica del Perú, 2003, p. 479.

10 Ibidem.

11 A. González Prada, "Apéndice I”, en: M. González Prada, Baladas, op. cit., p. 277.

12 A. González Prada, "Notas y variantes", en: ibidem, p. 268. Son los títulos que menciona el editor de "Baladas". Lamentablemente, no he tenido la oportunidad de consultar el manuscrito para comprobar el resto. Queda la posibilidad que incluyan también otros títulos inspirados por la obra de Mickiewicz. 
sólo resiste Granada

a pesar del hambre y peste ${ }^{13}$.

Y es, otra vez, una traducción libre del principio de la balada de Mickiewicz, conocida por el peruano quizás también a través de la traducción de Krystyn Ostrowski ${ }^{14}$, esta vez en verso:

Déjà du Christ l'étendard triomphant

Des Maures a vu fuir le reste;

Seule et sans peur Grenade se défend,

Mais Grenade en proie à la peste ${ }^{15}$.

El recuerdo de Mickiewicz no se queda en la balada inconclusa. Inesperadamente la figura de Almanzor vuelve a aparecer en uno de los escritos políticos de González Prada titulado Perú y Chile y se introduce en el sentido neologístico, una innovación fraseológica tal como habría que entenderla después de la lectura de la balada del poeta polaco:

Si el Perú se contajió [sic $]^{16}$ con la ferocidad araucana, Chile se contaminó con el virus peruano. El contacto de ambas naciones recuerda el abrazo de Almanzor, un medio de comunicarse la peste ${ }^{17}$.

La expresión aparece, no obstante, ininteligible sin el contexto necesario de la obra de Mickiewicz. El recuerdo del pasaje de Konrad Wallenrod debe estar grabado en la memoria de González Prada que lo cita sin aludir al poeta polaco, asimilándolo por completo.

El interés de Manuel González Prada por Polonia (desaparecida por aquel entonces, vale recordar) resulta ser mucho más profundo y vivo de lo que cabría esperar. Hablamos de una nación que se encuentra a casi doce mil kilómetros de distancia, en otro continente, y por mucho tiempo que haya pasado González Prada en Europa, parece curiosa la utilización de Polonia a modo de metáfora para describir la situación de su propio país:

Al no sacar una lección provechosa de nuestros descalabros, al no tratar de prevenir las nuevas tempestades arremolinadas encima de nuestra cabeza, mereceríamos que chilenos, argentinos y bolivianos cayeran sobre nosotros y nos convirtieran en la Polonia sudamericana ${ }^{18}$.

De hecho, el tema de la Polonia esclavizada por sus tres ocupantes no se queda reducido a lo que Karim Benmiloud denomina como "ensanchamiento

\footnotetext{
13 M. González Prada, Baladas, op. cit., p. 151.

14 Aunque también pudo haber conocido otras traducciones en prosa, de las que hubo varias.

15 A. Mickiewicz, Oeuvres (trad. Christien Ostrowski), Paris, H.-L. Delloye, 1841, p. 365.

16 En todas las citas se conserva la ortografía original.

17 M. González Prada, Pájinas libres, Paris, Tipografía de Paul Dupont, 1894, p. 79.

18 M. González Prada, Horas de lucha, op. cit., p. 34.
} 
del horizonte poético hacia otros espacios culturales"19. El investigador apunta hacia varios títulos que, según él, introducen una clara noción de "otredad": Desde lejos, El griego y La madre polaca, señalando que su "función principal" es la de "trascender los límites geográficos peruanos" 20 de las Baladas, añadiendo un toque exótico a la obra. No menciona, no obstante, que la balada La madre polaca, también inconclusa, puede haber nacido de la inspiración por el famoso poema de Mickiewicz, titulado A la madre polaca (Do Matki Polki), también traducido al francés por Krystian Ostrowski.

Aun así, Polonia se convierte por aquel entonces en todo un tópico para los románticos franceses y de ahí, posiblemente, el interés de González Prada quien, por su parte, vive muy intensamente la ocupación chilena de Lima en los años ochenta, cuando llega incluso a encarcelarse. De clara inspiración en Victor Hugo, que se hace obvia por la mención del escritor, es otro pasaje que aparece en Perú y Chile:

[...] no alcanzamos a imaginar la reprimida cólera de los peruanos sometidos a la dominación de Chile. Ellos confían i esperan en nosotros. [...] Como la Polonia de Victor Hugo, las poblaciones del Sur esperan, y esperan, y nadie $\mathrm{va}^{21}$.

En sus textos políticos se nota que Manuel González Prada siente una unión de destinos entre Polonia y Perú. La triste historia del estado polaco le parece oportuna para servir de lección a sus compatriotas. Lo que demuestra la necesidad de revisar el tema de las influencias extranjeras en la obra del peruano y a las comúnmente señaladas: alemanas, francesas e italianas, añadir y analizar otra, que es la del romanticismo polaco.

\section{Referencias bibliográficas}

BENMILOUD Karim

2006 "El segundo libro de las Baladas de Manuel González Prada: entre tragedia y sátira", en: Tauzin I. (ed.), Manuel González Prada: escritor de dos mundos, Lima, Instituto Francés de Estudios Andinos, pp. 215-226.

DELHOM Joël

2011 "Aproximación a las fuentes del pensamiento filosófico y político de Manuel González Prada: un bosquejo de biografía intelectual”, Iberoamericana 42, pp. 21-42.

FERRARI Américo

2003 La soledad sonora: voces poéticas del Perú e Hispanoamérica, Lima, Pontificia Universidad Católica del Perú.

19 K. Benmiloud, "El segundo libro de las Baladas de Manuel González Prada: entre tragedia y sátira", en: I. Tauzin (ed.), Manuel González Prada: escritor de dos mundos, Lima, Instituto Francés de Estudios Andinos, 2006, p. 216.

20 Ibidem.

${ }^{21}$ M. González Prada, Pájinas libres, op. cit., p. 88. 
GONZÁLEZ PRADA Manuel

1894 Pájinas libres, Paris, Tipografía de Paul Dupont.

1964 Horas de lucha, Lima, Ediciones Futuro.

1977 Ortometría: apuntes para una rítmica, Lima, Universidad Nacional Mayor de San Marcos. 2004 Baladas, Lima, Pontificia Universidad Católica de Perú.

MICKIEWICZ Adam

1841 Oeuvres (trad. Christien Ostrowski), Paris, H.-L. Delloye.

NÚÑEZ Estuardo

1968 “Manuel González Prada y la poesía”, Revista Hispánica Moderna 34, pp. 752-756.

VIGUERA MOLINS María Jesús

1999 “Imágenes de Almanzor”, en: Valdés Fernández F. (ed.), Almanzor y los terrores del milenio, Aguilar de Campo, Fundación Santa María la Real, pp. 9-22.

\section{The embrace of Almanzor: A note on the influence of Adam Mickiewicz on the work of Manuel González Prada}

Keywords: Manuel González Prada — Adam Mickiewicz — ballads — Poland.

\section{Abstract}

The note aims at indicating a new topic that needs to be analysed in the context of Manuel González Prada's work, that is, the influence of the compositions of the Polish romantic, Adam Mickiewicz. The author points out the passages taken by González Prada directly from the work of Mickiewicz. Among them appear not only the official translations but also fragments that are not made clear to those who do not know the work of the Polish poet. An obvious example is the motif of the „embrace of Almanzor”, a metaphorical concept devised by Mickiewicz, which González Prada uses on at least two occasions: as the title of an inconclusive ballad that was meant to be a free translation of Mickiewicz's ballad, as well as in a phraseological sense, in one of his political writings.

Fecha de recepción: 12 de noviembre de 2019

Fecha de aceptación: 2 de mayo de 2020 